\title{
The Emerging Concept of Intrinsic Plasticity: Activity-dependent Modulation of Intrinsic Excitability in Cerebellar Purkinje Cells and Motor Learning
}

\author{
Hyun Geun Shim ${ }^{1,2}$, Yong-Seok Lee ${ }^{1,2,3}$ and Sang Jeong Kim ${ }^{1,2,3 *}$ \\ ${ }^{1}$ Department of Physiology, Seoul National University College of Medicine, Seoul 03080, \\ ${ }^{2}$ Department of Biomedical Science, Seoul National University College of Medicine, Seoul 03080, \\ ${ }^{3}$ Neuroscience Research Institute, Seoul National University College of Medicine, Seoul 03080, Korea
}

\begin{abstract}
What is memory? How does the brain process the sensory information and modify an organisms behavior? Many neuroscientists have focused on the activity- and experience-dependent modifications of synaptic functions in order to solve these fundamental questions in neuroscience. Recently, the plasticity of intrinsic excitability (called intrinsic plasticity) has emerged as an important element for information processing and storage in the brain. As the cerebellar Purkinje cells are the sole output neurons in the cerebellar cortex and the information is conveyed from a neuron to its relay neurons by forms of action potential firing, the modulation of the intrinsic firing activity may play a critical role in the cerebellar learning. Many voltage-gated and/or $\mathrm{Ca}^{2+}$-activated ion channels are involved in shaping the spiking output as well as integrating synaptic inputs to finely tune the cerebellar output. Recent studies suggested that the modulation of the intrinsic excitability and its plasticity in the cerebellar Purkinje cells might function as an integrator for information processing and memory formation. Moreover, the intrinsic plasticity might also determine the strength of connectivity to the sub-cortical areas such as deep cerebellar nuclei and vestibular nuclei to trigger the consolidation of the cerebellardependent memory by transferring the information.
\end{abstract}

Key words: Cerebellum, Purkinje cells, Excitability, Ion channels, Neuronal plasticity, Learning

\section{INTRODUCTION}

Since Hebb’s rule was proposed, many neuroscientists have focused on the plastic changes in the synaptic neurotransmission

Received June 8, 2018, Revised June 28, 2018,

Accepted June 28, 2018

* To whom correspondence should be addressed. TEL: 82-2-740-8229, FAX: 82-2-763-9667 e-mail:sangjkim@snu.ac.kr within the given synapses such as long-term potentiation and depression (LTP and LTD, respectively) [1-5]. These persistent alterations of synaptic strength have been suggested to be a cellular basis of memory storage in the brain, which have been supported by the experimental observations in which experience- and usedependent modulation of the synaptic function are exhibited by certain forms of behavioral training $[4,6,7]$. There is, however, accumulating evidence supporting the idea that information storage may also involve the activity-dependent modulation of neuronal intrinsic excitability (intrinsic plasticity) in addition to 
synaptic plasticity [8-12]. The intrinsic plasticity is not confined to the single synapse but accompanies non-synaptic and global changes $[13,14]$. Therefore, the incongruity between synaptic and intrinsic plasticity may give rise to a controversy of which the global changes of neuronal excitability would seemingly distort the experience-dependent synaptic plasticity. Notably, synapsespecific and non-specific modifications synergistically contribute to the information processing and memory storage in the defined circuitry [13, 15-17]. When the synaptic plasticity occurs, several voltage-gated ion channels, which are related to the modulation of neuronal excitability, are endowed with activity-dependent upor down-regulation [18-21]. The activity-dependent modulation of ion channels regulates not only intrinsic excitability but also a dendritic integration of the synaptic inputs $[22,23]$. The intrinsic plasticity determines the net output of neurons by integrating the synaptic inputs and consecutively translating them into the action potential (AP) firing. Given that information is conveyed from a neuron (presynaptic) to its following neuron (postsynaptic) by AP firing, synergies between synaptic and intrinsic plasticity would play a role in maximizing information processing such as encoding, transfer and storage.

The inhibitory principal neurons in the cerebellar cortex, the cerebellar Purkinje cells (PCs) integrate excitatory and inhibitory inputs from widely spread dendrite branches. Various sensory information from the pre-cerebellar region and spinal cord project into the cerebellum through the mossy fiber (MF) which forms synapses with the cerebellar granule cells providing excitatory synaptic inputs into the PCs through its axon fibers, parallel fibers (PFs). Cerebellar PCs integrate the sensory information from the PF and then provide inhibitory instructive signals to the neurons in the vestibular nuclei (VN) and/or the deep cerebellar nuclei $(\mathrm{DCN})$ in order to generate motor output. This synaptic gain is modulated in an activity-dependent manner, which has long been considered as the cellular mechanism of cerebellumdependent motor learning [12, 24-27]. In addition to PF inputs, cerebellar PCs receive the other excitatory synaptic inputs from inferior olivary neuron axon fiber, climbing fiber (CF), encoding the feedback error signal corresponding to performances [28-31]. In order to control goal-directed movement, this sensory feedback of error signals dynamically regulates the cerebellar output [32, 33]. Indeed, the CF inputs onto the cerebellar PCs are regarded as the instructive signals in the cerebellar plasticity as the PF-PC synaptic plasticity is guided by timing rules between PF and CF activation $[34,35]$. When the $\mathrm{CF}$ inputs are conjunctive and paired with PF inputs, the excitatory synaptic transmission within PF-PC synapses is attenuated, called PF-PC long-term depression (LTD). In contrast, repetitive and strong PF electrical stimulation is found to induce long-term potentiation (LTP) at this synapses when CF inputs are omitted or non-paired [36]. PF-PC synaptic plasticity, in fact, is the heterosynaptic plasticity guided depending on the timing rules between PF and CF activation. The performance error signals are conveyed by $\mathrm{CF}$ to re-compute the motor signal from PCs, enabling finely tuned motor coordination through determining the cerebellar cortical activity. Many implications in cerebellar motor learning have suggested that the bidirectional plasticity of PF-PC synapses may be selectively engaged in specific behavioral paradigms [37, 38]. In spite of abundant studies on PFPC LTD/LTP associated with cerebellum dependent behaviors, it has been less elucidated how the net output of the cerebellar PCs is regulated in an activity-dependent manner. Since the cerebellar PCs are the sole output of the cerebellar cortex, the plasticity of the intrinsic excitability in the neurons might play a pivotal role in the modulation of cerebellar motor behavior and learning. In this review, we first cover the ion channels regulating the spiking activity of the cerebellar PCs and the cellular mechanisms of the plastic changes in excitability. Furthermore, we discuss the physiological significance of the intrinsic plasticity and how the synergies between synaptic and intrinsic plasticity contribute to behavioral outcomes.

\section{ION CHANNELS AND SPIKING ACTIVITY OF THE CEREBELLAR PCS}

The intrinsic excitability is influenced by the conductance of voltage-gated ion channels generating ionic current carried by $\mathrm{Na}^{+}$and $\mathrm{K}^{+}$ions $\left(I_{\mathrm{NA}}\right.$ and $I_{\mathrm{K}}$, respectively), which affects the passive and active membrane properties [39-42]. The ion channels are expressed in somatic and/or dendritic regions and modulate the temporal summation of the synaptic inputs and ability to generate AP firing in axon hillock [43, 44]. A balance of ion channel conductance and expressional composition determines the characteristics of spiking activity as well as the neuronal excitability. The cerebellar PCs show a distinct spiking activity which fires spontaneously at high frequency. Many studies illustrated that the changes in ion channel conductance alter the neuronal spiking activity and behavioral outcomes (Fig. 1).

\section{Voltage-gated $\mathrm{Na}^{+}$channels}

Voltage-gated $\mathrm{Na}^{+}$channels $\left(\mathrm{Na}_{\mathrm{V}}\right)$ are involved in determining active properties of neurons including voltage threshold for generating AP at the axon hillock and amplitude of AP spike [40-42]. In the cerebellar PCs, various subtypes of voltage-gated $\mathrm{Na}^{+}$channels are expressed, for instance, $\mathrm{Na}_{V} 1.1, \mathrm{Na}_{\mathrm{V}} 1.2$ and $\mathrm{Na}_{V} 1.6$ have been observed in rodent PCs [45-49]. Observation of $\left[\mathrm{Na}^{+}\right]_{\mathrm{i}}$ changes and electrophysiological recordings via outside-out patch clamp 

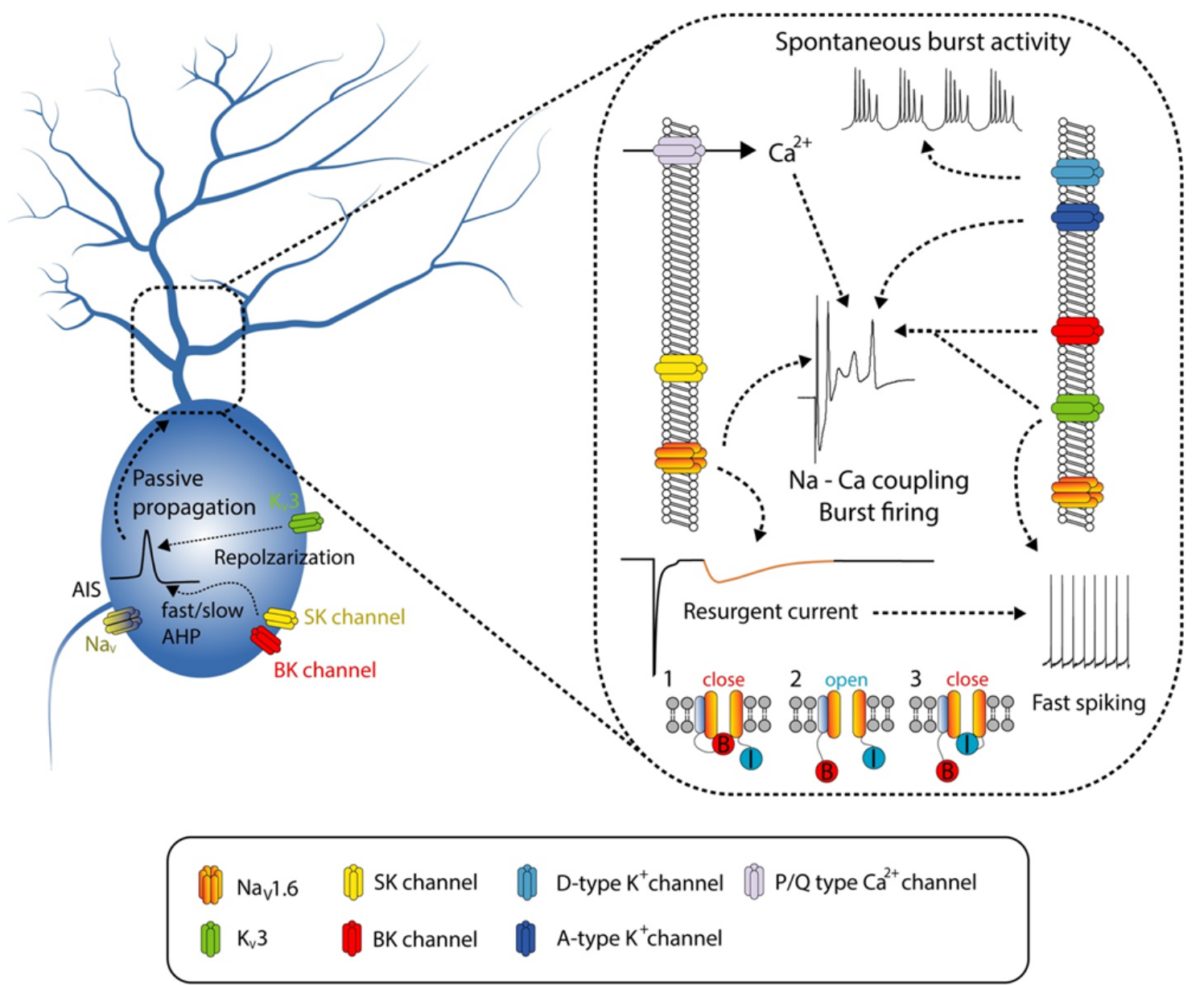

Fig. 1. Schematic illustration for ion channels shaping intrinsic excitability of the cerebellar PCs. Among various ion channels, this review focused on the resurgent $\mathrm{Na}^{+}$channel $\left(\mathrm{Na}_{V} 1.6\right)$, subthreshold-activated $\mathrm{K}^{+}$channels $\left(\mathrm{K}_{\mathrm{V}} 1.1,1.2\right.$ and 1.6; $\mathrm{K}_{\mathrm{V}} 1.4$ and $\mathrm{K}_{\mathrm{V}} 4$, D-type and A-type $\mathrm{K}^{+}$channel, respectively), suprathreshold-activated $\mathrm{K}^{+}$channels $\left(\mathrm{K}_{\mathrm{V}} 3\right.$ subfamily) and $\mathrm{Ca}^{2+}$-activated $\mathrm{K}^{+}$channels (SK and BK channel). Action potential is initiated at the action potential initial segment (AIS) near the axon hillock and then passively propagated into the dendritic area. Somatic SK and BK channels determine the AP spike waveform such as the amplitude of afterhyperpolarization (AHP) and $\mathrm{K}_{\mathrm{v}} 3$ subfamily regulates repolarization of AP. Because the cerebellar PCs, in particular, are fast-spiking neurons, mechanisms of rapid recovery from $\mathrm{Na}_{\mathrm{V}}$ inactivation is required to stably maintain $\mathrm{PC}$ spiking behavior. $\mathrm{Na}_{V} 1.6$ activity enables to rapidly fire the AP spikes via shortening refractory period. Various ion channels synergistically and dynamically modulate the dendrosomatic activity of the cerebellar PCs.

configuration have revealed that $\mathrm{Na}^{+}$spikes are generated within the somatic area of PC and then passively spread into the dendrites [49]. Despite some subtypes of $\mathrm{Na}_{\mathrm{V}}$ and changes in $\left[\mathrm{Na}^{+}\right]_{\mathrm{i}}$ in the PC dendrites were observed, backpropagation of AP into the dendrite from soma is absent, suggesting that the $\left[\mathrm{Na}^{+}\right]_{\mathrm{i}}$ influx and subtypes of $\mathrm{Na}^{+}$channels expressed in dendrites are not sufficient to generate AP in PC dendrites. In addition, electrophysiological recordings of $I_{\mathrm{Na}}$ in the cerebellar PCs have revealed a fast inactivating and/or a persistent conductance of $\mathrm{Na}^{+}[47,50]$.

Among subtypes of $\mathrm{Na}_{\mathrm{v}}, \mathrm{Na}_{\mathrm{v}} 1.6$ shows a distinct feature, which contributes to transient and resurgent components, but not to persistent components (Table 1 ). $\mathrm{Na}_{\mathrm{V}} \mathrm{l} .6$ was remarkably observed in the dendritic area in the cerebellar PCs [51]. The resurgent $I_{\mathrm{Na}}$ facilitates reopen $\mathrm{Na}_{V}$ when the membrane potential is repolarized to approximately $-40 \mathrm{mV}$ following the long period of depolarization exceeds $+30 \mathrm{mV}$ enough to produce maximal inactivation of $\mathrm{Na}_{\mathrm{V}}[52,53]$. This distinctive current flow contributes to ensuring the fast-spiking activity of the cerebellar PCs via the rapid openchannel block and unblock mechanism because the PCs, in particular, spontaneously fire AP spikes at high frequency. Resurgent current, carried by $\mathrm{Na}_{\mathrm{V}} 1.6$, has been found to be a mechanism by which the refractory period between AP firing is shortened by rapid recovery from inactivation of $I_{\mathrm{Na}}[54,55]$. Transgenic mice which resurgent $\mathrm{Na}^{+}$current is disrupted showed an abnormality in the spiking activity of PCs and manifestation of cerebellar ataxia and failure of motor coordination $[54,56]$. Recent studies 
Table 1. Active properties of resurgent $\mathrm{Na}^{+}$channels in the cerebellar PCs and their physiological and pathological roles

\begin{tabular}{ll}
\hline $\mathbf{N a}_{\mathbf{v}} \mathbf{1 . 6}$ (Resurgent $\mathbf{N a}^{+}$channel) \\
\hline Expression & Dendrite, Node of ranvier \\
Gating properties & Sensitivity for tetrodotoxin \\
& Evoked by a step repolarization to $-30 \mathrm{mV}$ \\
& Maximum current at $\mathrm{Vm}=-30 \sim-40 \mathrm{mV}$ \\
& $\mathrm{V}_{1 / 2 \text { activation }}=-40 \mathrm{mV}$, rising time $=5 \sim 6 \mathrm{~ms}$ \\
& $\mathrm{~V}_{1 / 2 \text { inactivation }}=-62 \mathrm{mV}$ (low $\left.\mathrm{Na}+\right),-53 \mathrm{mV}$ (high $\mathrm{Na}+$ ), $\tau_{\text {decay }}=20 \sim 30 \mathrm{~ms}$ \\
& Reopening Na $\mathrm{Na}_{\mathrm{V}}$ when the membrane potential is repolarized to approximately $-40 \mathrm{mV}$ \\
& Shortens the refractory period between action potentials, high-frequency firing appears to be facilitated \\
Impact on excitability & Reduced spontaneous firing rates \\
& Increased spike adaptation \\
Ablation & Cerebellar ataxia \& Dysfunction of motor coordination \\
& Impairment of water maze and delayed eyeblink conditioning \\
\hline
\end{tabular}

have shown that $\mathrm{Na}_{\mathrm{V}}$ channel auxiliary subunit FGF14'b' isoform is involved in controlling the resurgent current and excitability of PCs [57]. In parallel with previous observations, ablation of this auxiliary subunit manifests the abnormality of the firing activity in PCs and motor behavior $[57,58]$. Interestingly, inactivation of $\mathrm{Na}_{\mathrm{V}} 1.6$ affects not only the motor performance but also associative classical conditioning and spatial memory formation. Purkinje cell-specific deletion of Scn8a, encoding $\mathrm{Na}_{V} 1.6$, impaired the performance in the delayed eyeblink conditioning and the Morris water maze [59].

\section{Voltage-gated $\mathrm{K}^{+}$channels and $\mathrm{Ca}^{2+}$-activated $\mathrm{K}^{+}$channels}

$\mathrm{K}^{+}$channels are another major players in determining the excitability of the neurons. As molecular techniques have been advanced, various subtypes of $\mathrm{K}^{+}$channels and their gating properties have been characterized [60]. Like $\mathrm{Na}^{+}$channels, many $\mathrm{K}^{+}$ channels have shown quite distinct and divergent gating properties depending on the types of auxiliary proteins. $\mathrm{K}^{+}$channels are classified into several types, including voltage-gated channels $\left(K_{V}\right)$, $\mathrm{Ca}^{2+}$-activated $\mathrm{K}^{+}$channels $\left(\mathrm{K}_{\mathrm{Ca}}\right)$, inwardly rectifying channels (inward rectifier) and $\mathrm{Na}^{+}$-activated $\mathrm{K}^{+}$channels. In this review, we focused on the roles of several $\mathrm{K}_{V}$ subfamilies (Table 2) and $\mathrm{Ca}^{2+}$ activated $\mathrm{K}^{+}$channels (Table 2 ) in intrinsic firing properties of the cerebellar PCs.

Considering the Hodgkin-Huxley model, ionic flow carried by $\mathrm{Na}^{+}$and $\mathrm{K}^{+}$determines the active and passive properties of neurons. Of interest, $\mathrm{K}^{+}$conductance controls the resting membrane potential, membrane resistance, neuronal excitability, duration of $\mathrm{AP}$ and delay time to fire AP spike. Electrophysiological observations and immunohistochemistry data have shown that various types of $\mathrm{K}^{+}$channels are expressed in cerebellar PC soma and dendrites [61-68]. Gähwiler and Llano [61] observed that outward $I_{\mathrm{K}}$ is found to be elicited by membrane depolarization above $-30 \mathrm{mV}$ from excised somatic membrane. This suprathreshold-activated $I_{\mathrm{K}}$ shows sensitivity for general $\mathrm{K}^{+}$current inhibitors, tetraethylammonium (TEA) and 4-aminopyrimidine (4-AP), indicating that the $I_{\mathrm{K}}$ is governed by $\mathrm{K}_{\mathrm{v}} 3$ subfamily of $\mathrm{K}^{+}$channel $[66,69]$. This class of $\mathrm{K}^{+}$channels (especially $\mathrm{K}_{\mathrm{V}} 3.3$ and 3.4) repolarizes the $\mathrm{Na}^{+}$ spike discharge to maintain repetitive AP firing in both soma and dendritic area $[68,70-72]$. Therefore, dysfunction of this subfamily results in the impairment of repetitive AP spike discharge with a high frequency and an abnormal behavior [73]. In addition, the pharmacological inhibition with $1 \sim 10 \mathrm{mM}$ of 4 -AP or $2 \sim 5 \mathrm{mM}$ TEA affects the dendritic $\mathrm{Ca}^{2+}$ spike discharge, indicating that the dendritic $\mathrm{K}_{\mathrm{V}} 3$ channels contribute to shaping membrane excitability of PC dendrites as well as soma [74]. In spite of lacking backpropagation of $\mathrm{Na}^{+}$spikes into PC dendrites, membrane depolarization passively propagates into proximal and distal dendrites thereby generating regenerative $\mathrm{Na}^{+}$spikes and plateau potential which promotes bursting $\mathrm{Na}^{+}$spikes $[48,75]$. In addition, strong depolarization induced by $\mathrm{CF}$ activation leads to $\mathrm{Ca}^{2+}$ influx into the dendrite, resulting in the $\mathrm{Na}^{+}-\mathrm{Ca}^{2+}$ complex spike responses. The mixed $\mathrm{Na}^{+}-\mathrm{Ca}^{2+}$ spike discharge activates dendritic $\mathrm{K}_{\mathrm{V}} 3.1 / 3.3$ channels, enabling PC spiking activity to be stably maintained with high frequency though preventing $\mathrm{Na}^{+}$channel inactivation. When $\left[\mathrm{Ca}^{2+}\right]_{\mathrm{i}}$ is increased by CF activation, large conductance $\mathrm{Ca}^{2+}$-activated $\mathrm{K}^{+}(\mathrm{BK})$ channels are also activated. Interestingly, co-activation of $\mathrm{K}_{\mathrm{V}} 3$ and $\mathrm{BK}$ channels promotes coupling between $\mathrm{Na}^{+}$and $\mathrm{Ca}^{2+}$ spike discharge via reducing $\mathrm{Na}^{+}$channel inactivation, resulting in burst output of the cerebellar PCs [68].

Differently from $\mathrm{K}_{\mathrm{V}} 3$ family, some other types of $\mathrm{K}^{+}$channels show distinct gating properties, for instance, $K_{V} 1$ and 4 subtypes are activated at subthreshold voltage whereas $K_{V} 3$ family shows high voltage-activating and fast deactivating voltage dependency [76]. Storm [77] categorized the subthreshold-activated $\mathrm{K}^{+}$channels into 2 types depending on their sensitivity for 4 -AP 
Table 2. Active properties of voltage-gated $\mathrm{K}^{+}$channels in the cerebellar PCs and their physiological and pathological roles

\begin{tabular}{|c|c|c|}
\hline \multicolumn{3}{|c|}{$\mathrm{K}_{\mathrm{V}} 1.4 \& \mathrm{~K}_{\mathrm{V}} 4$ (A-type $\mathrm{K}^{+}$channel) } \\
\hline Expression & Dendrite & {$[70]$} \\
\hline \multirow[t]{5}{*}{ Gating properties } & Sensitivity for high concentration of 4-AP about 1 10 mM (insensitive for DTX) & {$[60,77,85]$} \\
\hline & Fast-activating and inactivating channel & \\
\hline & Activated at subthreshold voltage around $-60 \mathrm{mV}$ & \\
\hline & $\mathrm{V}_{1 / 2 \text { activation }}=-24.9 \mathrm{mV} ; \mathrm{V}_{1 / 2 \text { inactivation }}=-69.2 \mathrm{mV}$ & \\
\hline & $\tau_{\text {deactivation }}$ at $-70 \mathrm{mV}: 3 \sim 4 \mathrm{~ms}$ & \\
\hline \multirow[t]{3}{*}{ Impact on excitability } & Acceleration of AP spike & {$[82,84-87]$} \\
\hline & Firing frequency firing pattern (rhythmic Na-Ca spike burst) & \\
\hline & Subthreshold variation of membrane properties & \\
\hline $\begin{array}{l}\text { Impact on plasticity and } \\
\text { learning }\end{array}$ & Eyeblink conditioning derives dendritic excitability underlying downregulation of A-type K+ channel & {$[116,117]$} \\
\hline \multicolumn{3}{|c|}{$K_{V} 1.1, K_{V} 1.2, K_{V} 1.6\left(D-t y p e ~ K^{+}\right.$channel) } \\
\hline Expression & Dendrite & [70] \\
\hline \multirow[t]{5}{*}{ Gating properties } & Sensitivity for low concentration of 4-AP about $0.2 \sim 1 \mathrm{mM}$ and DTX $(2.8 \sim 25 \mathrm{nM})$ & {$[60,77]$} \\
\hline & Low-threshold and non-inactivating channel & \\
\hline & Activated at $-40 \sim-50 \mathrm{mV}$ & \\
\hline & $\mathrm{V}_{1 / 2 \text { activation }}=-20 \sim-30 \mathrm{mV}\left(\mathrm{K}_{\mathrm{V}} 1.2:-5 \sim 5 \mathrm{mV}\right)$ & \\
\hline & $\tau_{\text {deactivation }}=14 \sim 23 \mathrm{~ms}$ & \\
\hline \multirow[t]{3}{*}{ Impact on excitability } & Spike frequency and adaption, dendritic excitability & {$[82,83]$} \\
\hline & Amplitude and duration of rebound depolarization & \\
\hline & Spontaneous bursts & \\
\hline \multicolumn{3}{|l|}{$\mathrm{K}_{\mathrm{v}} 3.3 \& \mathrm{~K}_{\mathrm{v}} 3.4$} \\
\hline Expression & Soma and Dendrite & {$[69,70]$} \\
\hline \multirow[t]{4}{*}{ Gating properties } & Sensitivity for TEA & [68] \\
\hline & Rapid activating at suprathreshold and rapidly inactivating channel & \\
\hline & Peak amplitude at $30 \mathrm{mV}$ from $-70 \mathrm{mV}$ & \\
\hline & $\mathrm{V}_{1 / 2 \text { activation }}=-23.0 \mathrm{mV}, \tau_{\text {decay }}=0.66 \mathrm{~ms}$ & \\
\hline \multirow[t]{2}{*}{ Impact on excitability } & Repolarize the membrane potential and maintain repetitive firing & {$[68,71]$} \\
\hline & Dendritic burst firing through $\mathrm{Ca}^{2+}-\mathrm{Na}^{+}$coupling & \\
\hline $\begin{array}{l}\text { Impact on plasticity and } \\
\text { learning }\end{array}$ & Deletion of $K_{v} 3.1 / 3.3$ causes ataxic behavior & [73] \\
\hline
\end{tabular}

concentration and on the gating properties, A-type and D-type $\mathrm{K}_{\mathrm{V}}$ channels, governed by $\mathrm{K}_{\mathrm{V}} 1.4, \mathrm{~K}_{\mathrm{V}} 4 . \mathrm{X}$ and $\mathrm{K}_{\mathrm{V}} 1.1,1.2,1.6$, respectively. D-type $\mathrm{K}^{+}$channels, sensitive to dendrotoxin (DTX) and low concentration of 4-AP, are well known for determining spike output timing, latency and threshold for AP firing onset and firing frequency $[14,77-81]$. In the cerebellar PCs, large depolarization can induce $\mathrm{Na}^{+}-\mathrm{Ca}^{2+}$ coupling in dendritic area leading to slowly depolarized potential (SDP), facilitating $\mathrm{Na}^{+}$burst spike generation. Pharmacological inhibition of the D-type currents shortens the SDP and reduces latency to $\mathrm{Ca}^{2+}$ spikes [65], suggesting that the D-type channels are involved in the regulation of dendritic excitability. Application of DTX in cerebellar slices also increases spontaneous rhythmic activity through the enhancement of rebound firing, indicating that D-type $I_{\mathrm{K}}$ plays a modulatory role in defining spiking pattern in PCs [82]. In addition, $\mathrm{K}_{\mathrm{V}} 1$.2-containing $\mathrm{K}^{+}$channels have been shown to inhibit the spontaneous and nonspecific $\mathrm{Ca}^{2+}$ activity in the PC dendrites to encode motor timing signals. Furthermore, these ion channels contribute to the synaptic integration of PF inputs [83]. Taken together, low-threshold activated and non-inactivating $\mathrm{D}$-type $\mathrm{K}^{+}$channels take a part in the integration and generation of finely tuned signals in PCs, thereby signal tuning within physiological appropriate ranges.

Previous studies have shown that A-type and D-type $\mathrm{K}^{+}$channels play similar physiological roles. For example, the A-type $I_{\mathrm{K}}$ contributes to spike acceleration and determines the firing patterns in the cerebellar PCs $[84,85]$. Strikingly, this subfamily of $\mathrm{K}^{+}$channels is absent in PC somata or dissociated PC, suggesting an exclusive dendritic expression (and axon fiber). In PC dendrites, $\mathrm{K}_{\mathrm{V}} 3$ family is also expressed and regulates dendritic active properties. Given the distinct gating properties of A-type $\mathrm{K}^{+}$channels from $\mathrm{K}_{\mathrm{V}} 3$ family, this subfamily of $\mathrm{K}^{+}$channels is implicated in regulating the subthreshold variations of the membrane potential and processing the synaptic inputs $[86,87]$.

Instead of dendritic $\mathrm{Na}^{+}$channels, cerebellar PC dendrites express $\mathrm{Ca}^{2+}$ channels with high density. Therefore, strong depolarization causes synchronization of the passively conducted $\mathrm{Na}^{+}$ 
Table 3. Active properties of $\mathrm{Ca}^{2+}$-activated $\mathrm{K}^{+}$channels in the cerebellar PCs and their physiological and pathological roles

\begin{tabular}{|c|c|c|}
\hline \multicolumn{3}{|c|}{ SK channel (SK2 subfamily) } \\
\hline Expression & Soma and Dendrite & {$[90]$} \\
\hline Gating properties & $\begin{array}{l}\text { Voltage-independent and } \mathrm{Ca}^{2+} \text { dependent channel } \\
\text { Activated by } \mathrm{Ca}^{2+} \text { influx through } \mathrm{P} / \mathrm{Q} \text { type } \mathrm{Ca}^{2+} \text { channel } \\
\text { Sensitivity for apamin }(63 \mathrm{pM})\end{array}$ & {$[60,89]$} \\
\hline Impact on excitability & $\begin{array}{l}\text { Regulation of firing frequency } \\
\text { Shaping fast afterhyperpolarization (AHP) amplitude } \\
\text { Climbing fiber-induced spike pause duration } \\
\text { Activity-dependent modulation of climbing fiber-evoked EPSP amplitude and dendritic local } \mathrm{Ca}^{2+} \text { transient }\end{array}$ & {$[13,90,95,98]$} \\
\hline $\begin{array}{l}\text { Impact on plasticity } \\
\text { and learning }\end{array}$ & $\begin{array}{l}\text { Activity-dependent downregulation of SK channel by eyeblink conditioning } \\
\text { Inhibition of SK channel prevents LTP-IE induction }\end{array}$ & {$[13,118]$} \\
\hline \multicolumn{3}{|l|}{ BK channel } \\
\hline Expression & Soma and Dendrite & {$[90]$} \\
\hline Gating properties & $\begin{array}{l}\text { Voltage- and } \mathrm{Ca}^{2+} \text {-dependent } \\
\mathrm{V}_{1 / 2 \text { activation }}=50 \mathrm{mV} \text { at } 4 \mu \mathrm{M}\left[\mathrm{Ca}^{2+}\right] \text { to }-30 \mathrm{mV} \text { at } 100 \mu \mathrm{M}\left[\mathrm{Ca}^{2+}\right]\end{array}$ & {$[60]$} \\
\hline Impact on excitability & $\begin{array}{l}\text { Generation of burst firing through cooperating with } \mathrm{K}_{\mathrm{V}} 3 \text { channels in dendrite } \\
\text { Climbing fiber-evoked spike pause and burst firing coupled to } \mathrm{Ca}^{2+} \text { channel } \\
\text { Shaping medium or slow component of AHP }\end{array}$ & {$[68,91-93]$} \\
\hline $\begin{array}{l}\text { Impact on plasticity } \\
\text { and learning }\end{array}$ & Dysfunction of SK and BK channels is related to cerebellar ataxia & {$[94-97]$} \\
\hline
\end{tabular}

spike and $\mathrm{Ca}^{2+}$ spike in dendrites to shape the appropriate spiking activity of PCs. The influx of dendritic $\mathrm{Ca}^{2+}$ can activate an ionic flow carried by $\mathrm{K}^{+}, \mathrm{Ca}^{2+}$-activated $\mathrm{K}^{+}$channels. These types of channels are classified into two; small conductance and large conductance $\mathrm{Ca}^{2+}$-activated $\mathrm{K}^{+}$channel (SK and BK channel, respectively) (Table 3). Both SK and BK channels are also implicated in controlling the spiking activity in PCs [88]. When the dendritic membrane is depolarized by synaptic inputs, local $\left[\mathrm{Ca}^{2+}\right]_{\mathrm{i}}$ is elevated through $\mathrm{P} / \mathrm{Q}$ type $\mathrm{Ca}^{2+}$ channels, leading to the activation of the SK channels [89]. The SK channels are expressed in PC somata as well as in dendrites. Interestingly, dendrosomatic electrical coupling is governed by SK2 channels in PC soma and dendrite [90]. In addition, somatic and dendritic SK channels show distinct roles in regulating PC activity. SK channels in soma set the maximal level of PC firing frequency, and on the other hand, dendritic SK channels determine the extent of dendritic regions contributing to the firing rates of PCs. The other types of $\mathrm{Ca}^{2+}$-activated $\mathrm{K}^{+}$channel, BK channels are also involved in the spiking activity in PCs. As we described above, co-activity of $\mathrm{K}_{\mathrm{V}} 3$ and $\mathrm{BK}$ channels modulates dendritic $\mathrm{Na}^{+}-\mathrm{Ca}^{2+}$ coupling burst elicited by CF inputs through suppression of $\mathrm{Na}^{+}$channel inactivation [68]. Both SK and BK channels are activated by $\mathrm{Ca}^{2+}$ entering through $\mathrm{P} / \mathrm{Q}$ type $\mathrm{Ca}^{2+}$ channels and regulate PC firing patterns. However, these channels differently contribute to firing behavior in PCs. SK channels have an impact on the setting intrinsic firing frequency [90] whereas BK channels are involved in the regulation of AP waveform and presumably climbing fiber responses $[68,91]$. Recent studies have shown that CF-evoked pause of spontaneous firing and generation of burst firing in PCs require BK channels coupled to $\mathrm{Ca}^{2+}$ channels $[92,93]$. Because SK and BK channels in PCs play a critical role in the regulation of firing behavior, dysfunction of these channels has been implicated in cerebellar disease such as ataxia. Mutations in $\mathrm{P} / \mathrm{Q}$ type $\mathrm{Ca}^{2+}$ channels resulted in the decrease in the precision of $\mathrm{PC}$ pacemaking activity and perfusion of 1-ethyl2-benzimidazolinone (EBIO), $\mathrm{K}_{\mathrm{Ca}}$ activator improves the regularity of spontaneous firing and motor performance [94]. In addition, dysregulation of SK and/or BK channels has been reported in various genetic ataxia animal models [94-97], suggesting that modulation of SK and BK channels may be therapeutic targets for cerebella disease and motor dysfunction.

\section{ACTIVITY-DEPENDENT PLASTICITY OF INTRINSIC EXCITABIL- ITY THROUGH ION CHANNEL MODULATION}

\section{Activity- and experience-dependent intrinsic plasticity and ion channels}

Many theories have implicated that the potentiation or depression of the synaptic transmission at the PF-PC synapses and nonsynaptic intrinsic plasticity are required for cerebellar-dependent learning and memory. Intriguingly, the intrinsic plasticity requires an activity-dependent modulation of ion channels (Fig. 2) [1315, 98-100]. The ion channels in the cerebellar PCs are regulated by various factors such as an activation of metabotropic receptor or synaptic plasticity-related intracellular signaling $[13,15,100$, 

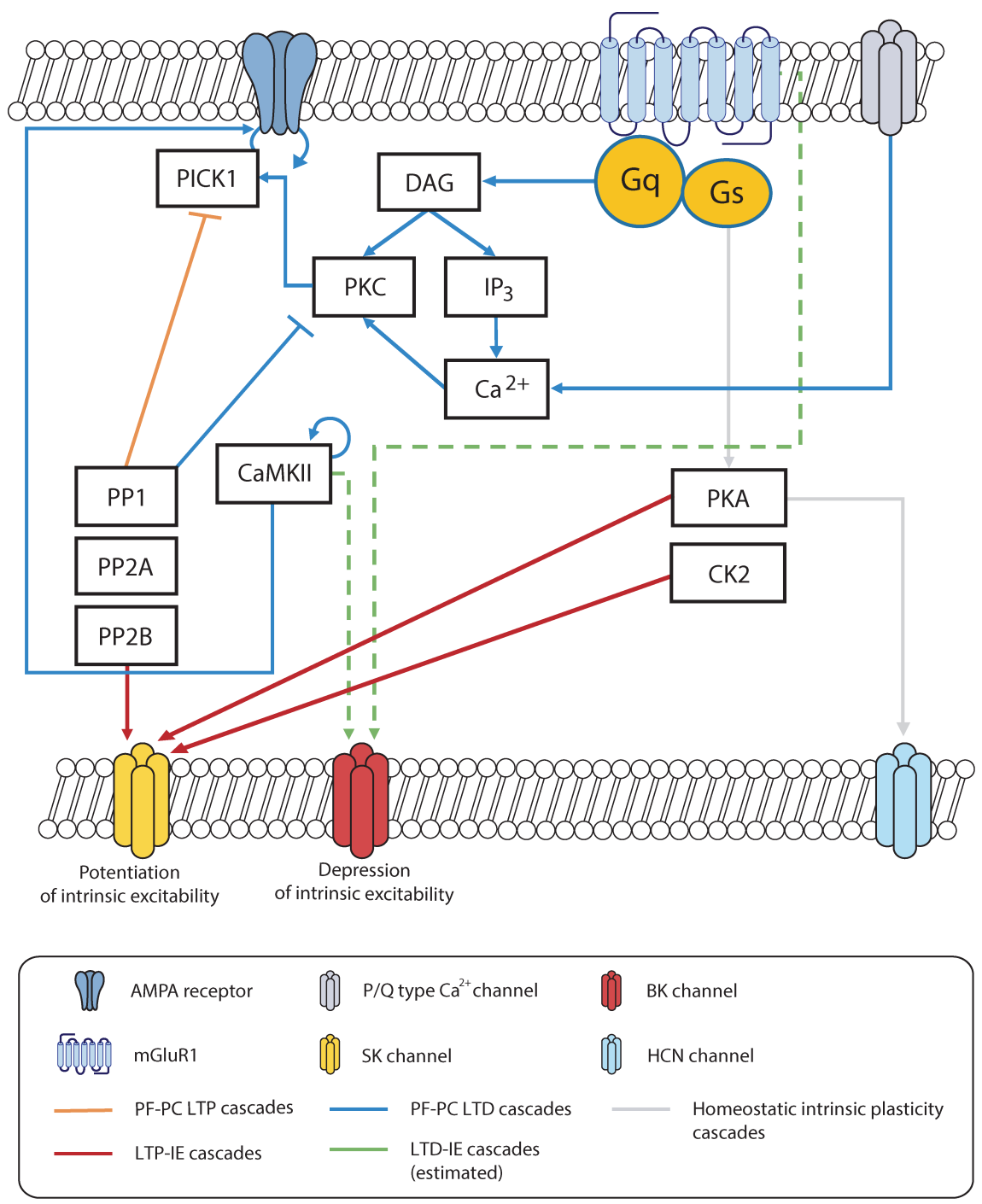

Fig. 2. Schematic illustration for molecular signal cascade for synaptic and intrinsic plasticity in the cerebellar PCs. Intrinsic plasticity indeed shares intracellular signal cascade for synaptic plasticity, in which LTP-IE requires activation of phosphatases such as PP1 and PP2B whereas LTD-IE is dependent on PKC activation. In contrast to abundant studies describing the cellular mechanisms and behavioral outcomes of LTPIE, detailed mechanisms of LTD-IE and its behavioral impact are still elusive although synaptic LTD has long been considered as cellular basis for cerebellar motor learning. In this review, BK channels are proposed for one plausible ion channels involved in LTD-IE. CaMKII activation is found to be involved in upregulation of BK channel activity (green dot line) in the VN neurons.
101]. When the chronic changes in network activity occur, the neuronal activity is homeostatically regulated in order to maintain the stability of network activity [102-105]. Prolonged application of tetrodotoxin (TTX) to organotypic cultures of cerebellar slices exhibits downregulation of the intrinsic excitability [100]. This homeostatic intrinsic plasticity is derived from an augmentation of hyperpolarization-activated cyclic nucleotide-gated (HCN) channel current $\left(I_{\mathrm{h}}\right)$ in the cerebellar PCs. Interestingly, the activitydependent upregulation of $I_{\mathrm{h}}$ in PCs requires an agonist-independent activity of metabotropic glutamate receptor 1 (mGluR1) and its $\mathrm{G}_{\mathrm{S}}$-coupled downstream of PKA signaling. Ablation of $\mathrm{HCN}$ channels in PCs exclusively disrupts the integration of inhibitory synaptic inputs and bi-stability of PC firing behavior [22]. Furthermore, HCN channels regulate a balance between excitation and inhibition through the integration of glutamatergic and GABAergic transmission and firing stability, thereby promoting memory formation at the late stages of cerebellar learning [106].

Recently, plasticity of the intrinsic excitability of the cerebellar PCs has been found to be accompanied by the synaptic plasticity $[13,15,107]$. In fact, PF-PC synaptic LTP derives the long-term potentiation of intrinsic excitability (LTP-IE). LTP-IE requires the downregulation of SK2 channels in dendritic area. The SK channel-dependent intrinsic plasticity may play a role in shaping the cerebellar PC output to adjust the impact of synaptic inputs within optimal ranges. The LTP-IE dampens the impact of PF inputs on the firing behavior of PCs, enabling effects of non-potentiated, weaker synaptic inputs on cellular output signal to minimize [13]. Interestingly, although local dendritic $\mathrm{Ca}^{2+}$ signaling is enhanced after formation of LTP-IE, prior induction of intrinsic plasticity prevents subsequent induction of synaptic LTP in PCs. Therefore, the role of intrinsic excitability in signal processing in the PCs is quite distinct from other types of neurons such as hippocampal 
pyramidal neurons or cortical neurons because enhanced $\mathrm{Ca}^{2+}$ signaling has been regarded as enlargements of synaptic inputs and increases in possibility of subsequent plasticity induction $[108,109]$. Considering that one important role of SK channels is setting the firing frequency in physiological limits, SK channelmediated LTP-IE may ensure that excitatory drive stays within the physiological limits and prevent non-specific subsequent synaptic plasticity induction thereby stabilizing and maximizing the information processing after learning.

In addition to the intrinsic plasticity followed by induction of LTP, the activity-dependent downregulation of PF-PC synaptic function accompanies the intrinsic plasticity. Yang and Santamaria [107] described that the potentiation of excitability in PCs is found following an induction of PF-PC LTD through downregulation of HCN channel conductance. Many observations have shown that the associative eyeblink conditioning training exerts modification of synaptic strength (PF-PC LTD) as well as intrinsic properties of the cerebellar PCs (potentiation of excitability) [110, 111]. Those described that the activity-dependent plasticity of intrinsic excitability may be homeostatically regulated which is similar to hippocampal intrinsic plasticity [18, 19]. Alternatively, Shim et al. [15] demonstrated that the intrinsic excitability is found to be decreased following induction of synaptic LTD. This result is parallel with the previous observation in which population spiking activity is attenuated by synaptic LTD induction [112]. Those contradictory results may be derived from different experimental conditions: Yang and Santamaria [107] delivered PF stimuli with somatic depolarization instead of CF activation whereas Shim et al. [15] synaptically induced synaptic plasticity by delivering simultaneous and conjunctive stimulation of PF and CF within specific time-window. Behavioral training could induce neural plasticity through divergent pathways. Thus, the intrinsic plasticity following synaptic depression may be presumably modulated in various aspects including potentiation or depression of firing rates, responsiveness of synaptic inputs or patterns of spiking activity to achieve maximizing the information storage in the cerebellar circuits.

Several observations have shown that associative eyeblink conditioning accompanies the experience- and use-dependent plasticity in the cerebellar cortex [113-117]. The experience-dependent plasticity of dendritic membrane excitability can be maintained 1 month after conditioning. Recently, it was shown that the delayed eyeblink conditioning increases intrinsic excitability and changes in AP waveforms, presumably derived from SK channel downregulation [118]. There are several evidence supporting that the memory trace in PCs is not just an increase or a decrease in firing rates. In fact, PC activity reflects adaptively timed activity pattern with intrinsic cellular mechanisms rather than a temporal pattern of excitatory or inhibitory synaptic inputs [113-115]. Taken together, experience-dependent modulation of PC intrinsic excitability is another form of memory engram for the cerebellardependent motor learning.

\section{Possible mechanisms for LTD-IE}

Since Ito hypothesized that synaptic LTD between PF-PC synapses is the principal elements for the cerebellar-dependent motor learning [24], much of investigation has been extensively focused on the cellular mechanism of the modification of synaptic function to account memory storage in the cerebellum and motor control. Unlikely to synaptic plasticity or LTP-IE, the underlying mechanism for LTD-IE has less been elucidated. Previous reports described that the intrinsic plasticity and synaptic plasticity indeed share intracellular signaling including protein phosphatase and/or protein kinases (Fig. 2). Several signaling molecules are required to induce PF-PC LTD such as protein kinase C (PKC) and CaMKII. In the hippocampus, $\mathrm{HCN}$ channel activity is mediated by PKC signaling during mGluR-dependent plasticity induction, which results in intrinsic plasticity. However, mGluR-PKC signaling suppresses $I_{\mathrm{h}}$, insisting that the LTD-IE in the cerebellar PCs may not be reflected by this signaling cascade. CaMKII is also known for a crucial element of synaptic and intrinsic plasticity. In the VN neurons, the activity-dependent plasticity of excitability requires bidirectional modulation of BK channels mediated by the balance between PKC and CaMKII activity [119-122]. The cerebellar PFPC synaptic LTD recruits CaMKII signaling which increases open probability of $\mathrm{BK}$ channels, thus this type of $\mathrm{K}_{\mathrm{Ca}}$ may be one possible candidate for the activity-dependent intrinsic plasticity in the cerebellar PCs. Since the cellular and molecular basis for LTD-IE of the cerebellar PCs remain unclear, the detailed mechanisms for the intrinsic plasticity should be further investigated.

Intrinsic plasticity plays a complementary role in integrating synaptic inputs and generating cellular output signal $[15,18,19$, $105,123,124]$. Synaptic-driven potentiation or depression of excitability show the same polarity with the corresponding direction of synaptic plasticity $[13,15]$, indicating that the modifications in synaptic strength are synergistically reflected into the final net output of PCs following plasticity. When the synaptic weight is strengthened, the PC output signal is more potentiated, not compensated by intrinsic properties. In addition, cerebellar PC intrinsic plasticity occurs in the branch-dependent manner [98], indicating that synaptic inputs from specific-branches are potentiated by increased membrane excitability limited in conditioned dendritic branches. Otherwise, the plastic changes in synaptic transmission might be contaminated by global changes of excitability and less 
reflected into the neuronal firing output signal.

\section{Upside down: to what extent does bidirectional intrinsic plasticity in the cerebellar dependent-motor learning do?}

What is the physiological consequence of the bidirectional modulation of intrinsic excitability following plasticity induction or behavioral training? Vestibulo-ocular reflex (VOR) and optokinetic response (OKR) is a representative behavioral paradigm of cerebellar-dependent motor learning. The VOR gain, the ratio of vestibular stimuli to adaptive eye-movement, can be increased or decreased depending on the learning paradigm. Boyden and Raymond [37] reported that the VOR gain-up and -down learning are selectively engaged by the aspects of synaptic plasticity. There was a supporting evidence of this view in which injection of mGluR1 antagonist into the cerebellar flocculus, the core area for VOR learning in the cerebellum, suppresses gain-up learning whereas gain-down learning is not affected by either agonist and antagonist of mGluR1 [38]. In addition, an ultrastructural observation shows a reduction of surface AMPA receptor following the adaptive eyemovement learning, suggesting that the cerebellar LTD would occur during the motor learning [125]. Most recently, it was revealed that the adaptive eye-movement training is associated with modifications of synaptic transmission at the PF-PC synapses [6], indicating the prominent roles of bidirectional synaptic plasticity at PF-PC synapses in the motor learning.

In contrast to Ito's cerebellar LTD theory, many studies have shown that the PF-PC LTD may not be a sufficient cellular mechanism underlying motor learnings in spite of abundant studies describing the critical roles of PF-PC LTD in VOR learning [28, 36, 126-129]. Miles and Lisberger $[130,131]$ proposed an alternative mechanism for motor learning, which suggests principal roles of $\mathrm{VN}$ neurons in the motor memory storage. There is, however, accumulating evidence showing that motor memory storage requires neuronal plasticity at multiple sites including neurons in the cerebellar cortex and VN $[12,27]$. Recently, a computational model for motor memory storage provided insights into the mechanism by which motor memory traces are seemingly transferred from cortical neurons (PC) to sub-cortical region (VN) [33, 132]. Cumulative experimental data has shown that encoding the adaptive motor memory in the cerebellar cortex occurs within a few hours and the critical time window for memory transfer is approximately $2.5 \sim 4$ hours after training $[133,134]$. Interestingly, Ito [129] recently suggested that an early adaption is dependent on the cerebellar cortical activity and the late phase of adaptation is accompanied by plasticity in the $\mathrm{VN}$ neurons. In parallel, the changes in the population spiking activity in $\mathrm{VN}$ neurons are manifested a day after training whereas there is no significant alteration of $\mathrm{VN}$ activity within an hour after training [135]. Until recently, this prediction for memory consolidation mechanism has not been investigated in a cellular and circuit level. Recent papers suggested that the intrinsic plasticity of the PCs might be the mechanism of the memory transfer from cerebellar cortex to sub-cortical areas [15, 88]. Collectively, computational implications and experimental observations have both agreed to Itos recent suggestion in which PF-PC synaptic plasticity may take part in the memory acquisition and plasticity in MF-VN synapses may be involved in longterm memory storage beyond two long-lasting conflicts for VOR memory: Marr-Albus-Ito's cerebellar LTD hypothesis vs. Miles and Lisberger' MF-VN synaptic plasticity theory.

Belmeguenai et al. [13] and Shim et al. [15] insisted that the intrinsic plasticity is modulated by synaptic activity patterndependent manner and this bidirectionality may function as an amplifier of the synaptic modification, enabling to transduce the finely tuned signal into the relay neurons such as neurons in DCN or VN. Given that the neural plasticity in the neurons in the cerebellar cortex and VN shows bidirectionality, the intrinsic plasticity would be also selectively engaged by certain forms of learning paradigm and the synergies with synaptic modulation may complete the scenario for the memory storage in the motor circuitry including cerebellum and $\mathrm{VN}$.

\section{THE FURTHER IMPLICATION OF INTRINSIC PLASTICITY IN THE MEMORY CIRCUITS}

There are many unanswered questions to be solved in terms of the intrinsic plasticity and behavior. In the classical view of the intrinsic plasticity, changes in excitability have been considered to play pivotal roles in promoting subsequent induction of synaptic plasticity through the up- or downregulation of dendritic ion channels. Thus, the intrinsic plasticity of neurons has been thought as simply a supportive mechanism for activity-dependent modification of synaptic function although the information is conveyed by the AP spikes between neurons. However, some of the suggestions have described that activity-dependent modifications of ion channels can also undergo experience-dependent long-term plasticity beyond changes in synaptic weight $[9,10,12,136-139]$. Furthermore, cumulative evidence has shown that memory trace should move from one brain region to another brain region to consolidate the long-term memory [125, 134, 140-144]. Intrinsic plasticity may be one plausible mechanism of memory transfer via modulating the strength of connectivity between memory circuits. Since the majority of researches have been performed to elucidate the mechanisms of cerebellar memory formation by using in-vitro cell lines or brain slices, the memory circuits should be 
assumed by using mathematical models that are made from biochemical observations, physiological recordings and behavioral assessments. Nevertheless, there has been an incongruity between theoretical models and actual experimental data which has to be reconciled. Recently, technical advances have enabled neuroscientists to overcome the experimental limitations and expand the research scope from modifications in individual neurons to macroscopic alteration involved in shaping the memory in vivo. Observations of neuronal ensemble activity from freely moving animals provide insights into how the information is processed within given local circuits. In learning period, neurons that show ensemble activity may encode the similar information and these neurons will be wired to fire together so that the connectivity between them will be strengthened. Indeed, engram cells who store memory show higher excitability than others, indicating that forming stable ensemble may reflect the induction of intrinsic plasticity in the neurons [138]. Collectively, experience-dependent modulation of neuronal excitability determines the net out signals in neurons and generates synchronized population activity to project the information into another brain area.

In the neural circuitry for the cerebellar-dependent motor learning, it is unclear how the information is transferred to the subcortical area including DCN and VN neurons from cerebellar PCs is unclear. In the hippocampus, electrophysiological recording and optogenetic manipulation of neural circuits have revealed that the specific frequency of an oscillatory neural activity, called sharp wave ripple (SWR), involves in memory transfer from the hippocampus to cortex [145-148]. During learning, an interplay between synaptic and intrinsic plasticity increases the number of SWR replay events and thereby consolidating the long-term memory. Although the oscillatory activity of the cerebellum has been reported, detailed mechanisms and its physiological roles in formation of memory engram in the motor learning circuits have yet to be investigated. During VOR learning, spike discharge in the cerebellar PCs shows a sinusoidal pattern in response to vestibular head movement [149-151]. Interestingly, the phase of the oscillatory pattern of PC firing activity is altered after the training session, indicating that the response timing to sensory stimuli may be endowed with plastic changes. Therefore, the intrinsic plasticity of PCs may modify the patterns to integrate the synaptic inputs and to generate the spike discharge in response to sensory information. Since memory is stored throughout the brain region, synergistic modulation of circuit dynamics might play critical roles. Various cutting-edge technologies enable to monitor the activity of large neuronal population and to manipulate the strength of neural circuits and corresponding behavioral outcomes. For example, recent studies using wide-field and high resolution in-vivo two- photon $\mathrm{Ca}^{2+}$ imaging approaches from behaving animals revealed the groundbreaking finding of the how the cerebellar granule cells process the sensory information $[152,153]$. These results from in vivo experiments lead us to re-evaluate the previously established hypothesis of the intrinsic excitability based on the results largely obtained from in vitro experiments. Many studies suggest that the PC modulates the membrane potential of the $\mathrm{VN}$ neurons by providing a tonic inhibition or strong hyperpolarization to induce rebound burst firing of neurons in DCN or VN. Although plasticity in both cerebellar cortex and VN play roles in the VOR memory storage, the neural plasticity occurs at the distinct time window [133-135, 154]. These observations have suggested the serial relationship of neural plasticity between the cerebellar cortex and $\mathrm{VN}$, it is, however, still elusive how the memory is transferred from cerebellar cortex to sub-cortical area. Cell type- and engram cellspecific tagging and manipulation with a high temporal and spatial resolution may help elucidating the role of PC output modulation during VOR training and memory transfer period. The modular structure of the cerebellar cortex has been considered as an unit for an information processing, thus ensemble activity of the cerebellar PCs may provide strong instructive signals to $\mathrm{VN}$ neurons [155]. Investigation from freely moving awake animals may give us the insight into the circuit mechanisms for sensory information processing and memory storage in the cerebellar motor learning circuits.

\section{ACKNOWLEDGEMENTS}

We thank Misun Mun, Gaeun Park and Ludmilla Penarrubia for proofreading the manuscript. This study was supported by National Research Foundation of Korea (NRF) Grant funded by the Korean government (MSIP) (2012R1A5A2A44671346; NRF2017M3C7A1029611 and Small Grant for Exploratory Research, Grant 2016R1D1A1A02937282).

\section{REFERENCES}

1. Hebb DO (1949) The organization of behavior: a neuropsychological theory. Wiley, New York, NY.

2. Shigemoto R, Abe T, Nomura S, Nakanishi S, Hirano T (1994) Antibodies inactivating mGluR1 metabotropic glutamate receptor block long-term depression in cultured Purkinje cells. Neuron 12:1245-1255.

3. Kashiwabuchi N, Ikeda K, Araki K, Hirano T, Shibuki K, Takayama C, Inoue Y, Kutsuwada T, Yagi T, Kang Y, Aizawa S, Mishina M (1995) Impairment of motor coordination, Purkinje cell synapse formation, and cerebellar long-term 
depression in GluR $\delta 2$ mutant mice. Cell 81:245-252.

4. Tsien JZ, Huerta PT, Tonegawa S (1996) The essential role of hippocampal CA1 NMDA receptor-dependent synaptic plasticity in spatial memory. Cell 87:1327-1338.

5. Shouval HZ, Bear MF, Cooper LN (2002) A unified model of NMDA receptor-dependent bidirectional synaptic plasticity. Proc Natl Acad Sci U S A 99:10831-10836.

6. Inoshita T, Hirano T (2018) Occurrence of long-term depression in the cerebellar flocculus during adaptation of optokinetic response. eLife 7:e36209.

7. Nguyen-Vu TB, Zhao GQ, Lahiri S, Kimpo RR, Lee H, Ganguli S, Shatz CJ, Raymond JL (2017) A saturation hypothesis to explain both enhanced and impaired learning with enhanced plasticity. eLife 6:e20147.

8. Gittis AH, du Lac S (2006) Intrinsic and synaptic plasticity in the vestibular system. Curr Opin Neurobiol 16:385-390.

9. Zhang W, Linden DJ (2003) The other side of the engram: experience-driven changes in neuronal intrinsic excitability. Nat Rev Neurosci 4:885-900.

10. Kim SJ, Linden DJ (2007) Ubiquitous plasticity and memory storage. Neuron 56:582-592.

11. Frick A, Magee J, Johnston D (2004) LTP is accompanied by an enhanced local excitability of pyramidal neuron dendrites. Nat Neurosci 7:126-135.

12. Gao Z, van Beugen BJ, De Zeeuw CI (2012) Distributed synergistic plasticity and cerebellar learning. Nat Rev Neurosci 13:619-635.

13. Belmeguenai A, Hosy E, Bengtsson F, Pedroarena CM, Piochon C, Teuling E, He Q, Ohtsuki G, De Jeu MT, Elgersma Y, De Zeeuw CI, Jörntell H, Hansel C (2010) Intrinsic plasticity complements long-term potentiation in parallel fiber input gain control in cerebellar Purkinje cells. J Neurosci 30:1363013643.

14. Hyun JH, Eom K, Lee KH, Ho WK, Lee SH (2013) Activitydependent downregulation of D-type $\mathrm{K}^{+}$channel subunit Kv1.2 in rat hippocampal CA3 pyramidal neurons. J Physiol 591:5525-5540.

15. Shim HG, Jang DC, Lee J, Chung G, Lee S, Kim YG, Jeon DE, Kim SJ (2017) Long-term depression of intrinsic excitability accompanied by synaptic depression in cerebellar Purkinje cells. J Neurosci 37:5659-5669.

16. Rancz EA, Häusser M (2010) Dendritic spikes mediate negative synaptic gain control in cerebellar Purkinje cells. Proc Natl Acad Sci U S A 107:22284-22289.

17. Mittmann W, Häusser M (2007) Linking synaptic plasticity and spike output at excitatory and inhibitory synapses onto cerebellar Purkinje cells. J Neurosci 27:5559-5570.
18. Brager DH, Johnston D (2007) Plasticity of intrinsic excitability during long-term depression is mediated through mGluRdependent changes in $I_{\mathrm{h}}$ in hippocampal CA1 pyramidal neurons. J Neurosci 27:13926-13937.

19. Fan Y, Fricker D, Brager DH, Chen X, Lu HC, Chitwood RA, Johnston D (2005) Activity-dependent decrease of excitability in rat hippocampal neurons through increases in $I_{\mathrm{h}}$. Nat Neurosci 8:1542-1551.

20. Jung SC, Hoffman DA (2009) Biphasic somatic A-type K channel downregulation mediates intrinsic plasticity in hippocampal CA1 pyramidal neurons. PLoS One 4:e6549.

21. Nelson AB, Faulstich M, Moghadam S, Onori K, Meredith A, du Lac S (2017) BK channels are required for multisensory plasticity in the oculomotor system. Neuron 93:211-220.

22. Nolan MF, Malleret G, Lee KH, Gibbs E, Dudman JT, Santoro B, Yin D, Thompson RF, Siegelbaum SA, Kandel ER, Morozov A (2003) The hyperpolarization-activated HCN1 channel is important for motor learning and neuronal integration by cerebellar Purkinje cells. Cell 115:551-564.

23. Vaidya SP, Johnston D (2013) Temporal synchrony and gamma-to-theta power conversion in the dendrites of CA1 pyramidal neurons. Nat Neurosci 16:1812-1820.

24. Ito M (1982) Cerebellar control of the vestibulo-ocular reflex-around the flocculus hypothesis. Annu Rev Neurosci 5:275296.

25. Ito M (1986) Long-term depression as a memory process in the cerebellum. Neurosci Res 3:531-539.

26. Ito M (2002) Historical review of the significance of the cerebellum and the role of Purkinje cells in motor learning. Ann NY Acad Sci 978:273-288.

27. Boyden ES, Katoh A, Raymond JL (2004) Cerebellum-dependent learning: the role of multiple plasticity mechanisms. Annu Rev Neurosci 27:581-609.

28. Ke MC, Guo CC, Raymond JL (2009) Elimination of climbing fiber instructive signals during motor learning. Nat Neurosci 12:1171-1179.

29. Guo CC, Ke MC, Raymond JL (2014) Cerebellar encoding of multiple candidate error cues in the service of motor learning. J Neurosci 34:9880-9890.

30. Kimpo RR, Rinaldi JM, Kim CK, Payne HL, Raymond JL (2014) Gating of neural error signals during motor learning. eLife 3:e02076.

31. Streng ML, Popa LS, Ebner TJ (2017) Climbing fibers predict movement kinematics and performance errors. J Neurophysiol 118:1888-1902.

32. Bloedel JR, Bracha V (1995) On the cerebellum, cutaneomuscular reflexes, movement control and the elusive engrams of 
memory. Behav Brain Res 68:1-44.

33. Yamazaki T, Nagao S (2012) A computational mechanism for unified gain and timing control in the cerebellum. PLoS One 7:e33319.

34. Safo PK, Regehr WG (2005) Endocannabinoids control the induction of cerebellar LTD. Neuron 48:647-659.

35. Suvrathan A, Payne HL, Raymond JL (2016) Timing rules for synaptic plasticity matched to behavioral function. Neuron 92:959-967.

36. Jörntell H, Hansel C (2006) Synaptic memories upside down: bidirectional plasticity at cerebellar parallel fiber-Purkinje cell synapses. Neuron 52:227-238.

37. Boyden ES, Katoh A, Pyle JL, Chatila TA, Tsien RW, Raymond JL (2006) Selective engagement of plasticity mechanisms for motor memory storage. Neuron 51:823-834.

38. Titley HK, Heskin-Sweezie R, Broussard DM (2010) The bidirectionality of motor learning in the vestibulo-ocular reflex is a function of cerebellar mGluR1 receptors. J Neurophysiol 104:3657-3666.

39. Hodgkin AL, Huxley AF (1945) Resting and action potentials in single nerve fibres. J Physiol 104:176-195.

40. Hodgkin AL, Huxley AF, Katz B (1952) Measurement of current-voltage relations in the membrane of the giant axon of Loligo. J Physiol 116:424-448.

41. Hodgkin AL, Huxley AF (1952) A quantitative description of membrane current and its application to conduction and excitation in nerve. J Physiol 117:500-544.

42. Hodgkin AL, Huxley AF (1952) Currents carried by sodium and potassium ions through the membrane of the giant axon of Loligo. J Physiol 116:449-472.

43. Stuart G, Häusser M (1994) Initiation and spread of sodium action potentials in cerebellar Purkinje cells. Neuron 13:703712.

44. Clark BA, Monsivais P, Branco T, London M, Häusser M (2005) The site of action potential initiation in cerebellar Purkinje neurons. Nat Neurosci 8:137-139.

45. Brysch W, Creutzfeldt OD, Lüno K, Schlingensiepen R, Schlingensiepen KH (1991) Regional and temporal expression of sodium channel messenger RNAs in the rat brain during development. Exp Brain Res 86:562-567.

46. Vega-Saenz de Miera EC, Rudy B, Sugimori M, Llinás R (1997) Molecular characterization of the sodium channel subunits expressed in mammalian cerebellar Purkinje cells. Proc Natl Acad Sci U S A 94:7059-7064.

47. Schaller KL, Caldwell JH (2003) Expression and distribution of voltage-gated sodium channels in the cerebellum. Cerebel$\operatorname{lum} 2: 2-9$.
48. de Ruiter MM, De Zeeuw CI, Hansel C (2006) Voltage-gated sodium channels in cerebellar Purkinje cells of mormyrid fish. J Neurophysiol 96:378-390.

49. Callaway JC, Ross WN (1997) Spatial distribution of synaptically activated sodium concentration changes in cerebellar Purkinje neurons. J Neurophysiol 77:145-152.

50. Kay AR, Sugimori M, Llinás R (1998) Kinetic and stochastic properties of a persistent sodium current in mature guinea pig cerebellar Purkinje cells. J Neurophysiol 80:1167-1179.

51. Caldwell JH, Schaller KL, Lasher RS, Peles E, Levinson SR (2000) Sodium channel $\mathrm{Na}_{\mathrm{V}} 1.6$ is localized at nodes of ranvier, dendrites, and synapses. Proc Natl Acad Sci U S A 97:5616-5620.

52. Raman IM, Bean BP (1997) Resurgent sodium current and action potential formation in dissociated cerebellar Purkinje neurons. J Neurosci 17:4517-4526.

53. Afshari FS, Ptak K, Khaliq ZM, Grieco TM, Slater NT, McCrimmon DR, Raman IM (2004) Resurgent Na currents in four classes of neurons of the cerebellum. J Neurophysiol 92:2831-2843.

54. Khaliq ZM, Gouwens NW, Raman IM (2003) The contribution of resurgent sodium current to high-frequency firing in Purkinje neurons: an experimental and modeling study. J Neurosci 23:4899-4912.

55. Raman IM, Bean BP (2001) Inactivation and recovery of sodium currents in cerebellar Purkinje neurons: evidence for two mechanisms. Biophys J 80:729-737.

56. Valkova C, Liebmann L, Krämer A, Hübner CA, Kaether C (2017) The sorting receptor Rerl controls Purkinje cell function via voltage gated sodium channels. Sci Rep 7:41248.

57. Yan H, Pablo JL, Wang C, Pitt GS (2014) FGF14 modulates resurgent sodium current in mouse cerebellar Purkinje neurons. eLife 3:e04193.

58. Bosch MK, Carrasquillo Y, Ransdell JL, Kanakamedala A, Ornitz DM, Nerbonne JM (2015) Intracellular FGF14 (iFGF14) is required for spontaneous and evoked firing in cerebellar Purkinje neurons and for motor coordination and balance. J Neurosci 35:6752-6769.

59. Woodruff-Pak DS, Green JT, Levin SI, Meisler MH (2006) Inactivation of sodium channel $S c n 8 A\left(\mathrm{Na}_{\mathrm{V}} 1.6\right)$ in Purkinje neurons impairs learning in Morris water maze and delay but not trace eyeblink classical conditioning. Behav Neurosci 120:229-240.

60. Coetzee WA, Amarillo Y, Chiu J, Chow A, Lau D, McCormack T, Moreno H, Nadal MS, Ozaita A, Pountney D, Saganich M, Vega-Saenz de Miera E, Rudy B (1999) Molecular diversity of $\mathrm{K}^{+}$channels. Ann NY Acad Sci 868:233-285. 
61. Gähwiler BH, Llano I (1989) Sodium and potassium conductances in somatic membranes of rat Purkinje cells from organotypic cerebellar cultures. J Physiol 417:105-122.

62. Gruol DL, Dionne VE, Yool AJ (1989) Multiple voltage-sensitive $\mathrm{K}^{+}$channels regulate dendritic excitability in cerebellar Purkinje neurons. Neurosci Lett 97:97-102.

63. Gruol DL, Jacquin T, Yool AJ (1991) Single-channel $\mathrm{K}^{+}$currents recorded from the somatic and dendritic regions of cerebellar Purkinje neurons in culture. J Neurosci 11:1002-1015.

64. Etzion Y, Grossman Y (1998) Potassium currents modulation of calcium spike firing in dendrites of cerebellar Purkinje cells. Exp Brain Res 122:283-294.

65. Etzion Y, Grossman Y (2001) Highly 4-aminopyridine sensitive delayed rectifier current modulates the excitability of guinea pig cerebellar Purkinje cells. Exp Brain Res 139:419425.

66. Raman IM, Bean BP (1999) Ionic currents underlying spontaneous action potentials in isolated cerebellar Purkinje neurons. J Neurosci 19:1663-1674.

67. Martina M, Yao GL, Bean BP (2003) Properties and functional role of voltage-dependent potassium channels in dendrites of rat cerebellar Purkinje neurons. J Neurosci 23:5698-5707.

68. McKay BE, Turner RW (2004) Kv3 $\mathrm{K}^{+}$channels enable burst output in rat cerebellar Purkinje cells. Eur J Neurosci 20:729739.

69. Southan AP, Robertson B (2000) Electrophysiological characterization of voltage-gated $\mathrm{K}^{+}$currents in cerebellar basket and Purkinje cells: Kv1 and Kv3 channel subfamilies are present in basket cell nerve terminals. J Neurosci 20:114-122.

70. Sekirnjak C, Martone ME, Weiser M, Deerinck T, Bueno E, Rudy B, Ellisman M (1997) Subcellular localization of the $\mathrm{K}^{+}$ channel subunit Kv3.1b in selected rat CNS neurons. Brain Res 766:173-187.

71. Rudy B, McBain CJ (2001) Kv3 channels: voltage-gated $\mathrm{K}^{+}$ channels designed for high-frequency repetitive firing. Trends Neurosci 24:517-526.

72. Lien CC, Jonas P (2003) Kv3 potassium conductance is necessary and kinetically optimized for high-frequency action potential generation in hippocampal interneurons. J Neurosci 23:2058-2068.

73. Matsukawa H, Wolf AM, Matsushita S, Joho RH, Knöpfel T (2003) Motor dysfunction and altered synaptic transmission at the parallel fiber-Purkinje cell synapse in mice lacking potassium channels Kv3.1 and Kv3.3. J Neurosci 23:7677-7684.

74. Midtgaard J, Lasser-Ross N, Ross WN (1993) Spatial distribution of $\mathrm{Ca} 2+$ influx in turtle Purkinje cell dendrites in vitro: role of a transient outward current. J Neurophysiol 70:2455-
2469.

75. Llinás R, Sugimori M (1980) Electrophysiological properties of in vitro Purkinje cell dendrites in mammalian cerebellar slices. J Physiol 305:197-213.

76. Coetzee WA, Amarillo Y, Chiu J, Chow A, Lau D, McCormack T, Moreno H, Nadal MS, Ozaita A, Pountney D, Saganich M, Vega-Saenz de Miera E, Rudy B (1999) Molecular diversity of $\mathrm{K}^{+}$channels. Ann N Y Acad Sci 868:233-285.

77. Storm JF (1988) Temporal integration by a slowly inactivating $\mathrm{K}^{+}$current in hippocampal neurons. Nature 336:379-381.

78. Harvey AL (2001) Twenty years of dendrotoxins. Toxicon 39:15-26.

79. Dodson PD, Forsythe ID (2004) Presynaptic $\mathrm{K}^{+}$channels: electrifying regulators of synaptic terminal excitability. Trends Neurosci 27:210-217.

80. Cudmore RH, Fronzaroli-Molinieres L, Giraud P, Debanne D (2010) Spike-time precision and network synchrony are controlled by the homeostatic regulation of the D-type potassium current. J Neurosci 30:12885-12895.

81. Ovsepian SV, Steuber V, Le Berre M, O'Hara L, O'Leary VB, Dolly JO (2013) A defined heteromeric KV1 channel stabilizes the intrinsic pacemaking and regulates the output of deep cerebellar nuclear neurons to thalamic targets. J Physiol 591:1771-1791.

82. Haghdoust H, Janahmadi M, Behzadi G (2007) Physiological role of dendrotoxin-sensitive $\mathrm{K}+$ channels in the rat cerebellar Purkinje neurons. Physiol Res 56:807-813.

83. Khavandgar S, Walter JT, Sageser K, Khodakhah K (2005) Kv1 channels selectively prevent dendritic hyperexcitability in rat Purkinje cells. J Physiol 569:545-557.

84. Hounsgaard J, Midtgaard J (1988) Intrinsic determinants of firing pattern in Purkinje cells of the turtle cerebellum in vitro. J Physiol 402:731-749.

85. Sacco T, Tempia F (2002) A-type potassium currents active at subthreshold potentials in mouse cerebellar Purkinje cells. J Physiol 543:505-520.

86. Hoffman DA, Magee JC, Colbert CM, Johnston D (1997) $\mathrm{K}^{+}$ channel regulation of signal propagation in dendrites of hippocampal pyramidal neurons. Nature 387:869-875.

87. Johnston D, Hoffman DA, Poolos NP (2000) Potassium channels and dendritic function in hippocampal pyramidal neurons. Epilepsia 41:1072-1073.

88. Ryu C, Jang DC, Jung D, Kim YG, Shim HG, Ryu HH, Lee YS, Linden DJ, Worley PF, Kim SJ (2017) STIM1 regulates somatic $\mathrm{Ca}^{2+}$ signals and intrinsic firing properties of cerebellar Purkinje neurons. J Neurosci 37:8876-8894.

89. Womack MD, Chevez C, Khodakhah K (2004) Calcium-acti- 
vated potassium channels are selectively coupled to P/Q-type calcium channels in cerebellar Purkinje neurons. J Neurosci 24:8818-8822.

90. Womack MD, Khodakhah K (2003) Somatic and dendritic small-conductance calcium-activated potassium channels regulate the output of cerebellar Purkinje neurons. J Neurosci 23:2600-2607.

91. Edgerton JR, Reinhart PH (2003) Distinct contributions of small and large conductance $\mathrm{Ca}^{2+}$-activated $\mathrm{K}^{+}$channels to rat Purkinje neuron function. J Physiol 548:53-69.

92. Jin XH, Wang HW, Zhang XY, Chu CP, Jin YZ, Cui SB, Qiu DL (2017) Mechanisms of spontaneous climbing fiber dischargeevoked pauses and output modulation of cerebellar Purkinje cell in mice. Front Cell Neurosci 11:247.

93. Irie T, Trussell LO (2017) Double-nanodomain coupling of calcium channels, ryanodine receptors, and BK channels controls the generation of burst firing. Neuron 96:856-870.e4.

94. Walter JT, Alviña K, Womack MD, Chevez C, Khodakhah K (2006) Decreases in the precision of Purkinje cell pacemaking cause cerebellar dysfunction and ataxia. Nat Neurosci 9:389-397.

95. Sausbier M, Hu H, Arntz C, Feil S, Kamm S, Adelsberger H, Sausbier U, Sailer CA, Feil R, Hofmann F, Korth M, Shipston MJ, Knaus HG, Wolfer DP, Pedroarena CM, Storm JF, Ruth P (2004) Cerebellar ataxia and Purkinje cell dysfunction caused by $\mathrm{Ca}^{2+}$-activated $\mathrm{K}^{+}$channel deficiency. Proc Natl Acad Sci U S A 101:9474-9478.

96. Dell'Orco JM, Wasserman AH, Chopra R, Ingram MA, Hu YS, Singh V, Wulff H, Opal P, Orr HT, Shakkottai VG (2015) Neuronal atrophy early in degenerative ataxia is a compensatory mechanism to regulate membrane excitability. J Neurosci 35:11292-11307.

97. Egorova PA, Zakharova OA, Vlasova OL, Bezprozvanny IB (2016) In vivo analysis of cerebellar Purkinje cell activity in SCA2 transgenic mouse model. J Neurophysiol 115:28402851.

98. Ohtsuki G, Piochon C, Adelman JP, Hansel C (2012) SK2 channel modulation contributes to compartment-specific dendritic plasticity in cerebellar Purkinje cells. Neuron 75:108-120.

99. Hyun JH, Eom K, Lee KH, Bae JY, Bae YC, Kim MH, Kim S, Ho WK, Lee SH (2015) Kv1.2 mediates heterosynaptic modulation of direct cortical synaptic inputs in CA3 pyramidal cells. J Physiol 593:3617-3643.

100. Shim HG, Jang SS, Jang DC, Jin Y, Chang W, Park JM, Kim SJ (2016) mGlul receptor mediates homeostatic control of intrinsic excitability through $I_{\mathrm{h}}$ in cerebellar Purkinje cells. J
Neurophysiol 115:2446-2455.

101. Smith SL, Otis TS (2003) Persistent changes in spontaneous firing of Purkinje neurons triggered by the nitric oxide signaling cascade. J Neurosci 23:367-372.

102. Turrigiano G, Abbott LF, Marder E (1994) Activity-dependent changes in the intrinsic properties of cultured neurons. Science 264:974-977.

103. Rutherford LC, DeWan A, Lauer HM, Turrigiano GG (1997) Brain-derived neurotrophic factor mediates the activitydependent regulation of inhibition in neocortical cultures. J Neurosci 17:4527-4535.

104. Cudmore RH, Turrigiano GG (2004) Long-term potentiation of intrinsic excitability in LV visual cortical neurons. J Neurophysiol 92:341-348.

105. Nataraj K, Le Roux N, Nahmani M, Lefort S, Turrigiano G (2010) Visual deprivation suppresses L5 pyramidal neuron excitability by preventing the induction of intrinsic plasticity. Neuron 68:750-762.

106. Rinaldi A, Defterali C, Mialot A, Garden DL, Beraneck M, Nolan MF (2013) HCN1 channels in cerebellar Purkinje cells promote late stages of learning and constrain synaptic inhibition. J Physiol 591:5691-5709.

107. Yang Z, Santamaria F (2016) Purkinje cell intrinsic excitability increases after synaptic long term depression. J Neurophysiol 116:1208-1217.

108. Watanabe S, Hoffman DA, Migliore M, Johnston D (2002) Dendritic $\mathrm{K}^{+}$channels contribute to spike-timing dependent long-term potentiation in hippocampal pyramidal neurons. Proc Natl Acad Sci U S A 99:8366-8371.

109. Ramakers GM, Storm JF (2002) A postsynaptic transient $K^{+}$ current modulated by arachidonic acid regulates synaptic integration and threshold for LTP induction in hippocampal pyramidal cells. Proc Natl Acad Sci U S A 99:10144-10149.

110. Hauge SA, Tracy JA, Baudry M, Thompson RF (1998) Selective changes in AMPA receptors in rabbit cerebellum following classical conditioning of the eyelid-nictitating membrane response. Brain Res 803:9-18.

111. Fiala JC, Grossberg S, Bullock D (1996) Metabotropic glutamate receptor activation in cerebellar Purkinje cells as substrate for adaptive timing of the classically conditioned eyeblink response. J Neurosci 16:3760-3774.

112. Lev-Ram V, Mehta SB, Kleinfeld D, Tsien RY (2003) Reversing cerebellar long-term depression. Proc Natl Acad Sci U S A 100:15989-15993.

113. Johansson F, Jirenhed DA, Rasmussen A, Zucca R, Hesslow G (2014) Memory trace and timing mechanism localized to cerebellar Purkinje cells. Proc Natl Acad Sci U S A 111:14930- 
14934.

114. Halverson HE, Khilkevich A, Mauk MD (2015) Relating cerebellar Purkinje cell activity to the timing and amplitude of conditioned eyelid responses. J Neurosci 35:7813-7832.

115. Jirenhed DA, Rasmussen A, Johansson F, Hesslow G (2017) Learned response sequences in cerebellar Purkinje cells. Proc Natl Acad Sci U S A 114:6127-6132.

116. Schreurs BG, Tomsic D, Gusev PA, Alkon DL (1997) Dendritic excitability microzones and occluded long-term depression after classical conditioning of the rabbit's nictitating membrane response. J Neurophysiol 77:86-92.

117. Schreurs BG, Gusev PA, Tomsic D, Alkon DL, Shi T (1998) Intracellular correlates of acquisition and long-term memory of classical conditioning in Purkinje cell dendrites in slices of rabbit cerebellar lobule HVI. J Neurosci 18:5498-5507.

118. Titley HK, Watkins GV, Lin C, et al. (2018) Intrinsic excitability increase in cerebellar Purkinje cells following delay eyeblink conditioning in mice. bioRxiv (in press).

119. Smith MR, Nelson AB, Du Lac S (2002) Regulation of firing response gain by calcium-dependent mechanisms in vestibular nucleus neurons. J Neurophysiol 87:2031-2042.

120. Nelson AB, Gittis AH, du Lac S (2005) Decreases in CaMKII activity trigger persistent potentiation of intrinsic excitability in spontaneously firing vestibular nucleus neurons. Neuron 46:623-631.

121. McElvain LE, Bagnall MW, Sakatos A, du Lac S (2010) Bidirectional plasticity gated by hyperpolarization controls the gain of postsynaptic firing responses at central vestibular nerve synapses. Neuron 68:763-775.

122. van Welie I, du Lac S (2011) Bidirectional control of BK channel open probability by CAMKII and PKC in medial vestibular nucleus neurons. J Neurophysiol 105:1651-1659.

123. Mahon S, Charpier S (2012) Bidirectional plasticity of intrinsic excitability controls sensory inputs efficiency in layer 5 barrel cortex neurons in vivo. J Neurosci 32:11377-11389.

124. Grasselli G, He Q, Wan V, Adelman JP, Ohtsuki G, Hansel C (2016) Activity-dependent plasticity of spike pauses in cerebellar Purkinje cells. Cell Reports 14:2546-2553.

125. Wang W, Nakadate K, Masugi-Tokita M, Shutoh F, Aziz W, Tarusawa E, Lorincz A, Molnár E, Kesaf S, Li YQ, Fukazawa Y, Nagao S, Shigemoto R (2014) Distinct cerebellar engrams in short-term and long-term motor learning. Proc Natl Acad Sci U S A 111:E188-E193.

126. Wulff P, Schonewille M, Renzi M, Viltono L, Sassoè-Pognetto M, Badura A, Gao Z, Hoebeek FE, van Dorp S, Wisden W, Farrant M, De Zeeuw CI (2009) Synaptic inhibition of Purkinje cells mediates consolidation of vestibulo-cerebellar motor learning. Nat Neurosci 12:1042-1049.

127. Schonewille M, Belmeguenai A, Koekkoek SK, Houtman SH, Boele HJ, van Beugen BJ, Gao Z, Badura A, Ohtsuki G, Amerika WE, Hosy E, Hoebeek FE, Elgersma Y, Hansel C, De Zeeuw CI (2010) Purkinje cell-specific knockout of the protein phosphatase $\mathrm{PP} 2 \mathrm{~B}$ impairs potentiation and cerebellar motor learning. Neuron 67:618-628.

128. Schonewille M, Gao Z, Boele HJ, Veloz MF, Amerika WE, Simek AA, De Jeu MT, Steinberg JP, Takamiya K, Hoebeek FE, Linden DJ, Huganir RL, De Zeeuw CI (2011) Reevaluating the role of LTD in cerebellar motor learning. Neuron 70:4350.

129. Ito M (2013) Error detection and representation in the olivocerebellar system. Front Neural Circuits 7:1.

130. Miles FA, Lisberger SG (1981) The "error" signals subserving adaptive gain control in the primate vestibulo-ocular reflex. Ann N Y Acad Sci 374:513-525.

131. Miles FA, Lisberger SG (1981) Plasticity in the vestibuloocular reflex: a new hypothesis. Annu Rev Neurosci 4:273299.

132. Clopath C, Badura A, De Zeeuw CI, Brunel N (2014) A cerebellar learning model of vestibulo-ocular reflex adaptation in wild-type and mutant mice. J Neurosci 34:7203-7215.

133. Kassardjian CD, Tan YF, Chung JY, Heskin R, Peterson MJ, Broussard DM (2005) The site of a motor memory shifts with consolidation. J Neurosci 25:7979-7985.

134. Okamoto T, Endo S, Shirao T, Nagao S (2011) Role of cerebellar cortical protein synthesis in transfer of memory trace of cerebellum-dependent motor learning. J Neurosci 31:89588966.

135. Shutoh F, Ohki M, Kitazawa H, Itohara S, Nagao S (2006) Memory trace of motor learning shifts transsynaptically from cerebellar cortex to nuclei for consolidation. Neuroscience 139:767-777.

136. Zhou Y, Won J, Karlsson MG, Zhou M, Rogerson T, Balaji J, Neve R, Poirazi P, Silva AJ (2009) CREB regulates excitability and the allocation of memory to subsets of neurons in the amygdala. Nat Neurosci 12:1438-1443.

137. Park S, Kramer EE, Mercaldo V, Rashid AJ, Insel N, Frankland PW, Josselyn SA (2016) Neuronal allocation to a hippocampal engram. Neuropsychopharmacology 41:2987-2993.

138. Lisman J, Cooper K, Sehgal M, Silva AJ (2018) Memory formation depends on both synapse-specific modifications of synaptic strength and cell-specific increases in excitability. Nat Neurosci 21:309-314.

139. Crestani AP, Krueger JN, Barragan EV, Nakazawa Y, Nemes SE, Quillfeldt JA, Gray JA, Wiltgen BJ (2018) Metaplasticity 
contributes to memory formation in the hippocampus. Neuropsychopharmacology (in press).

140. Frankland PW, Bontempi B (2005) The organization of recent and remote memories. Nat Rev Neurosci 6:119-130.

141. Restivo L, Vetere G, Bontempi B, Ammassari-Teule M (2009) The formation of recent and remote memory is associated with time-dependent formation of dendritic spines in the hippocampus and anterior cingulate cortex. J Neurosci 29:8206-8214.

142. Squire LR, Wixted JT (2011) The cognitive neuroscience of human memory since H.M. Annu Rev Neurosci 34:259-288.

143. Preston AR, Eichenbaum H (2013) Interplay of hippocampus and prefrontal cortex in memory. Curr Biol 23:R764-R773.

144. Nagao S, Honda T, Yamazaki T (2013) Transfer of memory trace of cerebellum-dependent motor learning in human prism adaptation: a model study. Neural Netw 47:72-80.

145. Buzsáki G (1998) Memory consolidation during sleep: a neurophysiological perspective. J Sleep Res 7 Suppl 1:17-23.

146. Carr MF, Jadhav SP, Frank LM (2011) Hippocampal replay in the awake state: a potential substrate for memory consolidation and retrieval. Nat Neurosci 14:147-153.

147. Poo MM, Pignatelli M, Ryan TJ, Tonegawa S, Bonhoeffer T, Martin KC, Rudenko A, Tsai LH, Tsien RW, Fishell G, Mullins C, Gonçalves JT, Shtrahman M, Johnston ST, Gage FH, Dan Y, Long J, Buzsáki G, Stevens C (2016) What is memory? The present state of the engram. BMC Biol 14:40.

148. Tang W, Jadhav SP (2018) Sharp-wave ripples as a signature of hippocampal-prefrontal reactivation for memory during sleep and waking states. Neurobiol Learn Mem (in press).
149. Mizukoshi K, Kobayashi H, Ohashi N, Watanabe Y (1983) Quantitative analysis of the human visual vestibulo-ocular reflex in sinusoidal rotation. Acta Otolaryngol Suppl 393:5864.

150. Fukushima K, Chin S, Fukushima J, Tanaka M (1996) Simplespike activity of floccular Purkinje cells responding to sinusoidal vertical rotation and optokinetic stimuli in alert cats. Neurosci Res 24:275-289.

151. Fukushima K, Buharin EV, Fukushima J (1993) Responses of floccular Purkinje cells to sinusoidal vertical rotation and effects of muscimol infusion into the flocculus in alert cats. Neurosci Res 17:297-305.

152. Wagner MJ, Kim TH, Savall J, Schnitzer MJ, Luo L (2017) Cerebellar granule cells encode the expectation of reward. Nature 544:96-100.

153. Giovannucci A, Badura A, Deverett B, Najafi F, Pereira TD, Gao Z, Ozden I, Kloth AD, Pnevmatikakis E, Paninski L, De Zeeuw CI, Medina JF, Wang SS (2017) Cerebellar granule cells acquire a widespread predictive feedback signal during motor learning. Nat Neurosci 20:727-734.

154. Yamazaki T, Nagao S, Lennon W, Tanaka S (2015) Modeling memory consolidation during posttraining periods in cerebellovestibular learning. Proc Natl Acad Sci U S A 112:35413546.

155. Gao Z, Proietti-Onori M, Lin Z, Ten Brinke MM, Boele HJ, Potters JW, Ruigrok TJ, Hoebeek FE, De Zeeuw CI (2016) Excitatory cerebellar nucleocortical circuit provides internal amplification during associative conditioning. Neuron 89:645-657. 